\title{
Genetic and environmental relationships between body condition score and milk production traits in Canadian Holsteins
}

\author{
S. Loker, ${ }^{*}$ C. Bastin, $†$ F. Miglior, $¥ \S^{1}$ A. Sewalem, $₫ \S$ L. R. Schaeffer, ${ }^{*}$ J. Jamrozik, ${ }^{*}$ A. Ali,\# and V. Osbornell \\ ${ }^{*}$ Centre for Genetic Improvement of Livestock, Department of Animal and Poultry Science, University of Guelph, Guelph, \\ Ontario, Canada N1G 2W1 \\ †University of Liège, Gembloux Agro-Bio Tech, B-5030 Gembloux, Belgium \\ ‡Guelph Food Research Centre, Agriculture and Agri-Food Canada, Guelph, Ontario, Canada, N1G 5C9 \\ $\S$ Canadian Dairy Network, Guelph, ON, Canada, N1K 1E5 \\ \#Department of Mathematics and Statistics, Guelph, and \\ ॥Centre for Nutrition Modelling, University of Guelph, Guelph, ON, Canada N1G 2W1
}

\begin{abstract}
The objective of this research was to estimate genetic parameters of first-lactation body condition score (BCS), milk yield, fat percentage (Fat\%), protein percentage (Prot\%), somatic cell score (SCS), milk urea nitrogen (MUN), lactose percentage (Lact\%), and fat to protein ratio (F:P) using multiple-trait random regression animal models. Changes in covariances between BCS and milk production traits on a daily basis have not been investigated before and could be useful for determining which BCS estimated breeding values (EBV) might be practical for selection in the future. Field staff from Valacta milk recording agency (SainteAnne-de-Bellevue, QC, Canada) collected BCS from Québec herds several times per cow throughout the lactation. Average daily heritabilities and genetic correlations among the various traits were similar to literature values. On an average daily basis, BCS was genetically unfavorably correlated with milk yield (i.e., increased milk yield was associated with lower body condition). The unfavorable genetic correlation between BCS and milk yield became stronger as lactation progressed, but was equivalent to zero for the first month of lactation. Favorable genetic correlations were found between BCS with Prot\%, SCS, and Lact\% (i.e., greater BCS was associated with greater Prot\%, lower SCS, and greater Lact\%). These correlations were strongest in early lactation. On an average daily basis, BCS was not genetically correlated with Fat\% or MUN, but was negatively correlated with F:P. Furthermore, BCS at 5 and $50 \mathrm{~d}$ in milk (DIM) had the most favorable genetic correlations with milk production traits over the lactation (at 5, 50, 150, and 250 DIM). Thus, early lactation BCS EBV shows potential for selection. Regardless,
\end{abstract}

Received April 29, 2011.

Accepted September 16, 2011.

${ }^{1}$ Corresponding author: miglior@cdn.ca this study showed that the level of association BCS has with milk production traits is not constant over the lactation. Simultaneous selection for both BCS and milk production traits should be considered, mainly due to the unfavorable genetic correlation between BCS with milk yield.

Key words: body condition score, genetic correlation, milk production, random regression model

\section{INTRODUCTION}

In the past, dairy cattle selection programs in various countries were focused on production, whereas in recent years they have shifted toward more balanced breeding goals (Miglior et al., 2005). This is because selection on increased milk production has resulted in reduced health and fertility of dairy cattle (Veerkamp et al., 2001; Heringstad et al., 2003). Although milk production and feed intake are positively genetically correlated (Hooven et al., 1972; van Arendonk et al., 1991), the correlated response in feed intake is only enough to cover 40 to $48 \%$ of the extra energy requirements of increased milk production (van Arendonk et al., 1991; Veerkamp et al., 1995). Thus, genetically higher producing cows experience a more intense and extended early lactation negative energy balance than lower producers. These high-producing animals attempt to balance this energy deficit largely through mobilization of more tissue reserves than lower producers (Veerkamp and Emmans, 1995; Dechow et al., 2002). Increased extent and duration of negative energy balance in early lactation has been associated with greater health and fertility problems (Butler and Smith, 1989). It would be ideal to select for animals with high production that do not mobilize an excessive amount of tissue reserves. This could lead to selection for animals that balance their energy deficit via increased feed intake, which implies selection on genes in common between milk production and feed intake that are independent of BCS. 
Because the genetic correlation between feed intake and milk production is not unity, genetic progress for milk production would be slowed. Veerkamp and Brotherstone (1997) determined that selection for increased milk yield while maintaining BCS at its current level resulted in a reduction of overall (economic) genetic gain by $5 \%$. However, they did not account for reduced cost associated with improved health and fertility.

Before using BCS as a tool for improving health and fertility, it is first important to verify the relationship between BCS and other traits of economic importance. To our knowledge, no other study has analyzed BCS and milk production traits on a test-day (TD) basis. Instead, previous research has analyzed BCS as a single-record trait (taken at a specific stage of lactation) with cumulative milk (Dechow et al., 2001; Berry et al., 2003a), fat, and protein yields (Dechow et al., 2001). Veerkamp et al. (2001) analyzed BCS using a random regression sire model with cumulative 305-d milk, fat, and protein yields. The most similar analysis to the current study was by Berry et al. (2003b). They analyzed BCS and milk yield on a TD basis using random regression animal models to estimate genetic correlations between each trait and various fertility traits. However, those authors did not analyze BCS and milk yield as correlated traits. In other words, no other study has analyzed the change in covariance between BCS and milk production traits on a day-to-day basis. Observing changes in covariance between BCS and milk production traits on a daily basis may lead to more informed decisions regarding which BCS EBV in which stage of lactation may be more useful for selection with minimal unfavorable effect on milk production traits. The objective of this research was to estimate genetic parameters of BCS with milk production traits in firstlactation Canadian Holsteins using random regression animal models.

\section{MATERIALS AND METHODS}

Holstein TD records were collected from 2001 to 2008 for BCS, MUN, and lactose percentage (Lact\%) by Valacta (Sainte-Anne-de-Bellevue, QC, Canada) field staff from Québec herds. A previous study determined that BCS was strongly genetically correlated across the first 3 lactations (Loker et al., 2011). Therefore, only first-parity BCS records were used in the current study. One or more (up to 22) BCS records were available per cow. Body condition score was recorded on a scale from 1 (thin) to 5 (fat) in increments of 0.25 . These data were merged with the TD file provided by Canadian Dairy Network (Guelph, ON, Canada), which included records on first-lactation daily milk yield, fat percentage (Fat\%), protein percentage (Prot\%), and SCC, collected since 1988. Milk yield, Fat\%, Prot\%, and SCC were always recorded on the same day. The fat to protein ratio $(\mathbf{F}: \mathbf{P})$ trait was formed by dividing Fat\% by Prot\%. Somatic cell count was log-transformed to SCS. Pedigree records were provided by Canadian Dairy Network (Guelph, ON, Canada).

The data were split into 2 separate analyses because fewer records were available for MUN and Lact\% than for milk production traits; this is because MUN and Lact\% were collected by Valacta from Québec herds only, and milk production traits were available from herds nationwide. Analysis 1 included BCS, milk yield, Fat\%, Prot\%, and SCS, and analysis 2 included BCS, MUN, Lact\%, and F:P. For analysis 1, the top 50 herds with the most animals with BCS records were selected, because BCS was the trait with the least data available. For analysis 2, because BCS and MUN were the 2 traits with the least data available, the top 50 herds with the greatest average number of animals with BCS and MUN records [(number of BCS records + number of MUN records)/2] were selected. This ensured selection of herds with many BCS and MUN records for analysis 2. Data were restricted to records taken on DIM after calving between 5 and 305 d, total lactation length between 100 and $400 \mathrm{~d}$, and age at calving between 19 and $40 \mathrm{mo}$. Because there was an excess of milk production records, production data were limited to a minimum year of calving of 1999 (the minimum year of calving for cows with BCS records). Records in classes of herd $\times$ TD $($ HTD) with $<5$ records were deleted.

After edits, the data set used in analysis 1 included 23,037 BCS and 86,331 milk production (including SCS) records. There were 9,036 records for which BCS and milk production traits (and SCS) were recorded on the same day. The data set contained records for 10,917 cows from 50 herds, with an average of 163 animals with BCS records per herd and 217 animals with milk production and SCS records per herd. There were 1,672 sires with an average of 7 daughters per sire. Table 1 includes descriptive statistics of the complete edited data set used for analysis 1 before and after extracting 50 herds with the most animals with BCS records. Means and variances were very similar before and after extracting herds and applying edits, so the selected data were representative of the original data set.

The data set used in analysis 2 included 21,858 BCS, 21,916 MUN, 22,280 Lact\%, and 96,298 F:P records. There were $2,005,2,072$, and 7,981 records for which BCS was recorded on the same day as MUN, Lact\%, and F:P, respectively. The data set contained records for 12,097 cows from 50 herds, with an average of 153 , 110, 111, and 241 animals with BCS, MUN, Lact\%, and F:P records per herd, respectively. There were 1,760 
Table 1. Descriptive statistics of records in the complete edited data set before and after selecting 50 complete herds for analysis 1

\begin{tabular}{llcccc}
\hline Item & BCS & Milk $(\mathrm{kg})$ & Fat $(\%)$ & Protein $(\%)$ & SCS \\
\hline Before & & & & & \\
Mean & 2.78 & 25.76 & 3.81 & 3.27 & 2.13 \\
SD & 0.46 & 6.20 & 0.62 & 0.31 & 1.86 \\
After & & & & & \\
Mean & 2.81 & 29.11 & 3.85 & 3.31 & 2.20 \\
SD & 0.47 & 6.09 & 0.62 & 0.31 & 1.89 \\
Average records per cow & 3 & 8 & 8 & 8 & 8 \\
\hline
\end{tabular}

sires with an average of 7 daughters per sire. Table 2 includes descriptive statistics of the complete edited data set used for analysis 2 before and after extracting 50 herds with the greatest average number of animals with BCS and MUN records. Means and variances were very similar before and after extracting herds and applying edits, so the selected data were representative of the original data set.

Five classes of year of calving were formed, with 2 yr per class (1999-2000, 2001-2002, etc.). Eight classes of age at calving were formed $(\leq 24,25,26,27,28,29$, $30-31$, and $\geq 32 \mathrm{mo}$ ), and 4 seasons of calving were defined (January-March, April-June, July-September, and October-December). The identifications of the field staff person taking each score for BCS were not recorded.

The following model was used:

$$
\mathbf{y}=\mathbf{X} \boldsymbol{\beta}+\mathbf{Z}_{1} \mathbf{h}+\mathbf{Z}_{2} \mathbf{a}+\mathbf{Z}_{3} \mathbf{p}+\mathbf{e},
$$

where $\mathbf{y}$ was the vector of observations for BCS, milk yield, Fat\%, Prot\%, and SCS for analysis 1, or BCS, MUN, Lact\%, and F:P for analysis 2. The purpose of the analysis was to adjust records for fixed environmental factors, represented by term $\boldsymbol{\beta}$ in the model. Along with adjusting records for fixed effects, random components were also quantified.

For BCS, $\boldsymbol{\beta}$ was the vector of fixed effects for HTD, and of fixed regression coefficients for age $\times$ class of 2 yr of calving $\times$ season of calving (AYS) effect, $\mathbf{h}$ was the vector of random regression coefficients for herd $x$ class of $2 \mathrm{yr}$ of calving ( $\mathbf{H Y}$ ) effect, a was the vector of random regression coefficients for additive genetic effect, $\mathbf{p}$ was the vector of random regression coefficients for permanent environmental (PE) effect, and e was a vector of random residuals.

For milk production traits (and SCS), $\boldsymbol{\beta}$ was the vector of fixed effects for HTD, and of fixed regression coefficients for age $\times$ season of calving (AS), a was the vector of random regression coefficients for additive genetic effect, $\mathbf{p}$ was the vector of random regression coefficients for PE effect and, e was a vector of random residuals.

Last, $\mathbf{X}$ and $\mathbf{Z}_{\mathbf{i}}(\mathbf{i}=1-3)$ were incidence matrices assigning observations to effects. To clarify, PE effects are environmental effects that affect each of the animal's records. Random residual error is the remaining error in the model prediction after accounting for other effects in the model.

A random regression animal model was chosen for these traits because it allowed each animal to have a different shape of curve over the lactation (Schaeffer et al., 2000). As in Loker et al. (2011), Legendre polynomials of order 2 were used to describe regression curves for BCS. Only a limited number of BCS records were available per animal (3 on average), and a similar study by Berry et al. (2003b) showed little advantage of using Legendre polynomials of order 3 instead of order 2 ; order 4 was chosen for milk production traits to be similar to the Canadian TD model.

Table 2. Descriptive statistics of records in the complete edited data set before and after selecting 50 complete herds for analysis 2

\begin{tabular}{llccc}
\hline Item & BCS & $\begin{array}{c}\text { MUN } \\
(\mathrm{mg} / \mathrm{dL})\end{array}$ & $\begin{array}{c}\text { Lactose } \\
(\%)\end{array}$ & ${\mathrm{F}: \mathrm{P}^{1}}^{1}$ \\
\hline Before & & & & \\
Mean & 2.78 & 10.76 & 4.69 & 1.17 \\
SD & 0.46 & 3.30 & 0.18 & 0.17 \\
After & & & & \\
Mean & 2.82 & 10.71 & 4.71 & 1.16 \\
SD & 0.47 & 3.16 & 0.17 & 0.17 \\
Average records per cow & 3 & 4 & 4 & 8 \\
\hline
\end{tabular}

${ }^{1} \mathrm{~F}: \mathrm{P}=$ fat percentage to protein percentage ratio. 
Expectations and covariance structure for the random effects were

$$
\mathrm{E}(\mathbf{y})=\mathbf{X b}, \mathrm{E}(\mathbf{h})=\mathbf{0}, \mathrm{E}(\mathbf{a})=\mathbf{0}, \mathrm{E}(\mathbf{p})=\mathbf{0}, \mathrm{E}(\mathbf{e})=\mathbf{0}
$$

and

$$
\begin{gathered}
\mathrm{V}(\mathbf{h})=\mathbf{I} \otimes \mathbf{Q}_{0}, \mathrm{~V}(\mathbf{p})=\mathbf{I} \otimes \mathbf{P}_{0}, \mathrm{~V}(\mathbf{a})= \\
\mathbf{A} \otimes \mathbf{G}_{0}, \mathrm{~V}(\mathbf{e})=\mathbf{E},
\end{gathered}
$$

where $\otimes$ is the Kronecker product function (Searle, 1982), I represents an identity matrix, $\mathbf{A}$ is the additive relationship matrix, $\mathbf{Q}_{0}$ is a covariance matrix for $\mathrm{HY}$ regression coefficients, and $\mathbf{P}_{0}$ and $\mathbf{G}_{0}$ are (co)variance matrices for PE and genetic regression coefficients, respectively. Matrix E is a block-diagonal residual (co) variance matrix. Residual (co)variances were assumed heterogeneous across 3 intervals of DIM ( 5 to 45, 46 to 115, 116 to 305 DIM). Residual (co)variances among traits within the same DIM interval were allowed to differ from zero. All covariances among traits between different DIM intervals were assumed to be zero. All random effects were assumed normally distributed.

Variance components were estimated with a Bayesian approach via Gibbs sampling using DMU software (Madsen and Jensen, 2008). Prior values were set arbitrarily to 0.03 for variances and 0 for covariances. Posterior means of (co)variance components were estimated using 80,000 samples after a burn-in of 20,000 samples. The convergence of Gibbs samples was monitored by visual inspection of the plot of realizations for selected covariance components.

Daily heritability was defined as the ratio of additive genetic variance to phenotypic variance [the sum of additive genetic, $\mathrm{HY}$ (for BCS), $\mathrm{PE}$, and residual variances] on a given DIM. Average daily heritability and genetic and PE correlations were obtained by summing daily heritabilities, or daily genetic or PE correlations from 5 to 305 DIM and dividing by 301. Because BCS was included in 2 analyses, 2 average daily heritabilities were calculated for this trait. These 2 heritabilities were then averaged to produce an overall average daily heritability for BCS. Similarly for other parameters for BCS, results were averaged across the 2 analyses. All average daily heritabilities and genetic and PE correlations will be presented with posterior standard deviations in parentheses. Additionally, to determine if genetic or PE correlations differed from zero, 95\% Bayesian confidence intervals were calculated. If the interval in which $95 \%$ of the samples of correlations generated by Gibbs sampling did not contain zero, then the parameter was considered different from zero. For parameters calculated on a daily basis from 5 to 305
DIM, a Bayesian confidence interval was calculated every 30 DIM (e.g., 5, 35, 65, 95 DIM).

\section{RESULTS AND DISCUSSION}

Average daily heritabilities for BCS were similar between analyses: $0.22(0.02)$ and $0.19(0.02)$ for analyses 1 and 2, respectively. Average daily heritabilities for all traits are presented in Table 3, where they are compared with first-parity heritability estimates from Miglior et al. (2007), who used a similar model for production traits and SCS, and analyzed Canadian Holstein data collected from Québec herds in the first 3 parities. Estimates were similar to those of Miglior et al. (2007), although milk yield heritability was lower in the current study. Heritability estimates for BCS were in the range of literature values (Jones et al., 1999; Koenen et al., 2001; Berry et al., 2003b). A recent study by Bastin et al. (2010) used the same data source to analyze firstlactation BCS with a random regression animal model together with reproduction traits. That study reported an average daily heritability of 0.14 for BCS. The 0.07 difference in heritability between the current study and that of Bastin et al. (2010) could be due to differences in editing of the full data set or to modeling differences. Because a fixed HTD factor was not included in Bastin et al. (2010), effect of BCS assessor may have been confounded with the random HY factor in that study, resulting in a lower estimate of heritability for BCS (Loker et al., 2011) compared with the current study.

Estimates of daily heritability, genetic, PE, HY, and residual variances for BCS were very similar to those of Loker et al. (2011). Daily BCS heritability was in agreement with other sources, which established that BCS was the least heritable at the beginning of lactation and most heritable in mid to late lactation (Koenen et al., 2001; Berry et al., 2003b; Dechow et al., 2004; Bastin et al., 2010).

Residual correlations were very weak between BCS and milk production traits, but were moderate (as

Table 3. Average daily heritabilities (with posterior standard deviations in parentheses) of BCS, milk yield, fat percentage, protein percentage, SCS, MUN, lactose percentage, and fat percentage to protein percentage ratio $(\mathrm{F}: \mathrm{P})$

\begin{tabular}{lcc}
\hline Trait & $\begin{array}{c}\text { Current } \\
\text { study }\end{array}$ & $\begin{array}{c}\text { Miglior et al. } \\
(2007)\end{array}$ \\
\hline BCS & $0.21(0.02)$ & - \\
Milk yield & $0.38(0.02)$ & 0.52 \\
Fat percentage & $0.59(0.01)$ & 0.56 \\
Protein percentage & $0.60(0.02)$ & 0.58 \\
SCS & $0.15(0.01)$ & 0.19 \\
MUN & $0.36(0.02)$ & 0.39 \\
Lactose percentage & $0.52(0.03)$ & 0.48 \\
F:P & $0.42(0.01)$ & - \\
\hline
\end{tabular}

Journal of Dairy Science Vol. 95 No. 1, 2012 
Table 4. Average daily genetic correlations (above the diagonal) and permanent environmental correlations (below the diagonal) and posterior SD (in parentheses) among BCS, milk yield, fat percentage (Fat\%), protein percentage (Prot\%), and SCS

\begin{tabular}{|c|c|c|c|c|c|}
\hline & BCS & Milk & Fat $\%$ & Prot $\%$ & SCS \\
\hline $\mathrm{BCS}$ & & $-0.28(0.05)$ & $0.06(0.05)$ & $0.23(0.05)$ & $-0.17(0.06)$ \\
\hline Milk & $-0.19(0.03)$ & & $-0.51(0.02)$ & $-0.55(0.02)$ & $0.00(0.05)$ \\
\hline Fat $\%$ & $0.16(0.05)$ & $-0.31(0.03)$ & & $0.66(0.01)$ & $-0.08(0.04)$ \\
\hline Prot $\%$ & $0.34(0.04)$ & $-0.38(0.03)$ & $0.33(0.04)$ & & $-0.03(0.03)$ \\
\hline SCS & $0.03(0.03)$ & $-0.18(0.02)$ & $0.05(0.03)$ & $0.20(0.03)$ & \\
\hline
\end{tabular}

strong as 0.31) between milk production traits, especially in early lactation (5-45 DIM). Average daily PE and genetic correlations among the traits in analysis 1 and 2 are presented in Tables 4 and 5, respectively. All $\mathrm{PE}$ and genetic correlation posterior standard deviations were low.

Daily PE correlations between BCS and other traits from analysis 1 and 2 are shown in Figures 1 and 2, respectively. The PE correlation between BCS and milk yield became increasingly negative over the lactation (Figure 1). Bayesian confidence intervals calculated from 95 to 305 DIM did not contain zero. It is unusual that no positive environmental correlation was found between BCS and milk yield in early lactation. Dechow et al. (2002) found that management and environmental conditions that result in a fatter cow at calving are associated with greater milk production and a greater loss of body condition in early lactation. However, although changes in BCS and milk yield are related physiologically, these changes may not occur in perfect synchrony. In the current study, as lactation progressed, lower production was associated with greater BCS. Daily milk production normally decreases toward the end of lactation while cows are being fed to regain condition (Bauman and Currie, 1980). Permanent environmental correlations between BCS and Fat\% only differed from zero from 125 DIM onward (although the correlation did not differ from 0 at 305 DIM). Perhaps as BCS increased and milk yield decreased toward the end of lactation, fat yield remained stable such that Fat\% increased. The PE correlations between BCS and Prot $\%$ were positive and different from zero from early to late lactation. At no point in lactation did PE correlations between BCS and SCS differ from zero.
Bayesian confidence intervals for PE correlations between BCS and MUN at 35 and 65 DIM were negative and did not contain zero. Cows that mobilized more tissue reserves and experienced a lower BCS had higher MUN in early lactation. König et al. (2008) suggested that negative energy balance in early lactation was associated with an increase in MUN. Positive PE correlations were found between BCS and Lact\% that were considered different from zero at 65 and 95 DIM. This supports research that concluded that better conditioned cows are more fertile (Bastin et al., 2010) and that greater Lact\% is associated with better fertility (Reksen et al., 2002; Buckley et al., 2003). The negative PE correlations between BCS and F:P were considered different from zero at 35 and 65 DIM. In early lactation, the typical dairy cow will mobilize mainly adipose tissue (Bauman and Currie, 1980), and energy provided by protein mobilization is comparatively minor (Belyea et al., 1978; Schröder and Staufenbiel, 2006). Therefore, the negative PE correlation between BCS and F:P could be the result of increased tissue mobilization, leading to a decrease in BCS and a greater percentage of fat relative to percentage of protein mobilization. A scenario where a cow is already thin (such that little tissue mobilization occurs) is possible. However, that scenario is unlikely as producers typically manage the BCS of their cattle in preparation for tissue mobilization in early lactation (Bewley and Schutz, 2008). The average BCS curve for first-lactation cows from the Valacta data set (Loker et al., 2011) shows that the population begins lactation well conditioned and experiences a decline in BCS in early lactation.

Average daily genetic correlations (Tables 4 and 5) among trait pairs in common with Miglior et al. (2007)

Table 5. Average daily genetic correlations (above the diagonal) and permanent environmental correlations (below the diagonal), and posterior SD (in parentheses) among BCS, MUN, lactose percentage (Lact\%), and fat percentage to protein percentage ratio $(\mathrm{F}: \mathrm{P})$

\begin{tabular}{lcrrr}
\hline & \multicolumn{1}{c}{ BCS } & \multicolumn{1}{c}{ MUN } & \multicolumn{1}{c}{ Lact\% } & \multicolumn{1}{c}{ F:P } \\
\hline BCS & & $-0.03(0.07)$ & $0.11(0.06)$ & $-0.12(0.06)$ \\
MUN & $-0.08(0.06)$ & & $-0.20(0.05)$ & $0.31(0.04)$ \\
Lact\% & $0.002(0.004)$ & $0.05(0.08)$ & & $-0.12(0.04)$ \\
F:P & $-0.01(0.04)$ & $0.27(0.05)$ & $-0.19(0.06)$ & \\
\hline
\end{tabular}




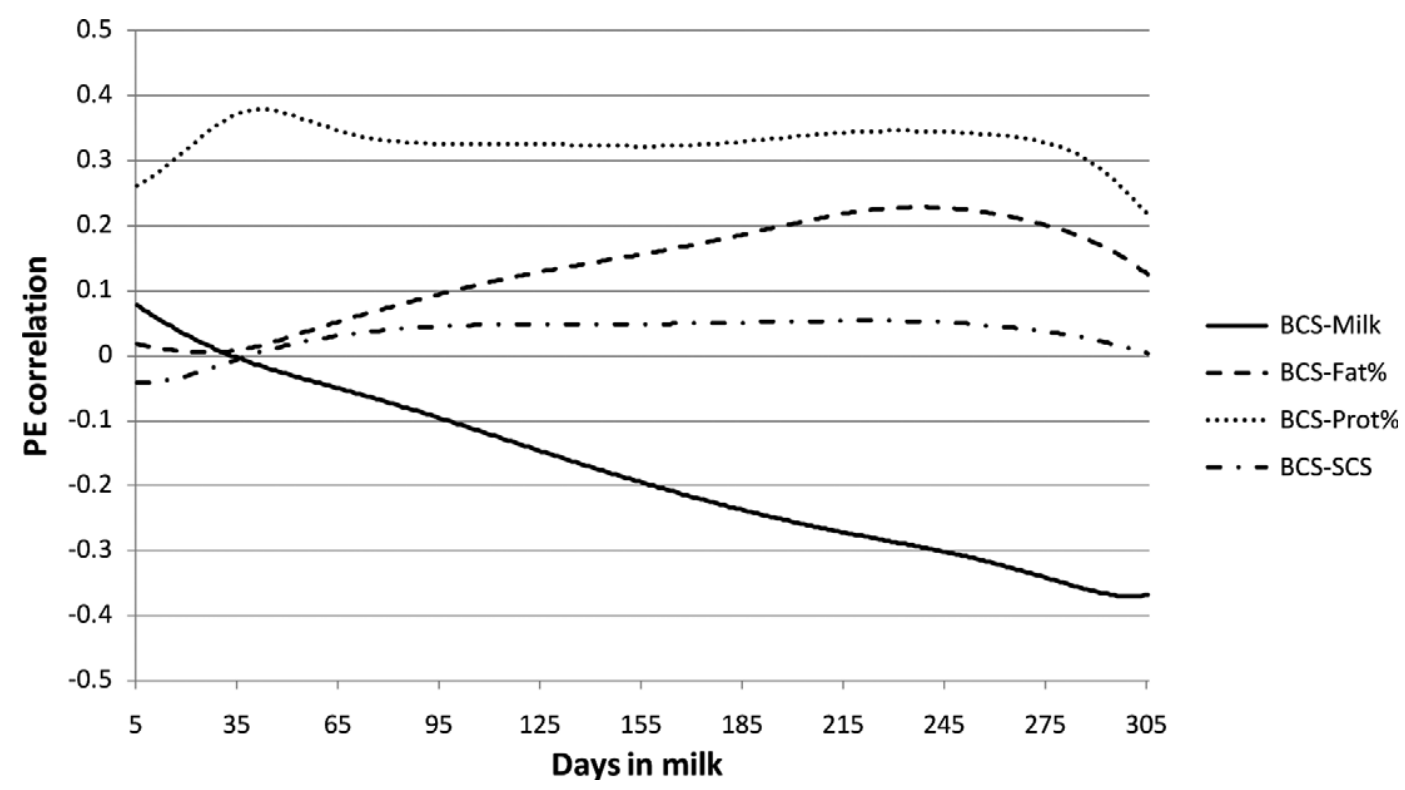

Figure 1. Estimates of permanent environmental (PE) correlations between BCS and milk yield, fat percentage (Fat\%), protein percentage (Prot\%), and SCS across DIM.

were similar in magnitude and sign to estimates of that study, with the exception of the genetic correlation between MUN and Lact\%, which was - 0.20 (0.05) in the current study and -0.04 in Miglior et al. (2007). As expected, a negative genetic correlation $[-0.28(0.05)]$ was found between BCS and TD milk yield, which was different from zero. Other studies have found a negative genetic correlation between BCS and cumulative milk yield that ranged from -0.30 to -0.46 (Veerkamp et al., 2001; Berry et al., 2003a). The genetic correlation between BCS and Fat\% [0.06 (0.05)] was not different from zero. Veerkamp et al. (2001) found that BCS had a negative genetic correlation with 305-d fat yield of -0.27 . Perhaps, in the current study, a genetically higher BCS was associated with a genetically lower producing cow, which produced less milk and fat such that Fat\% was unaffected. The current study found a positive genetic association between BCS and Prot\%

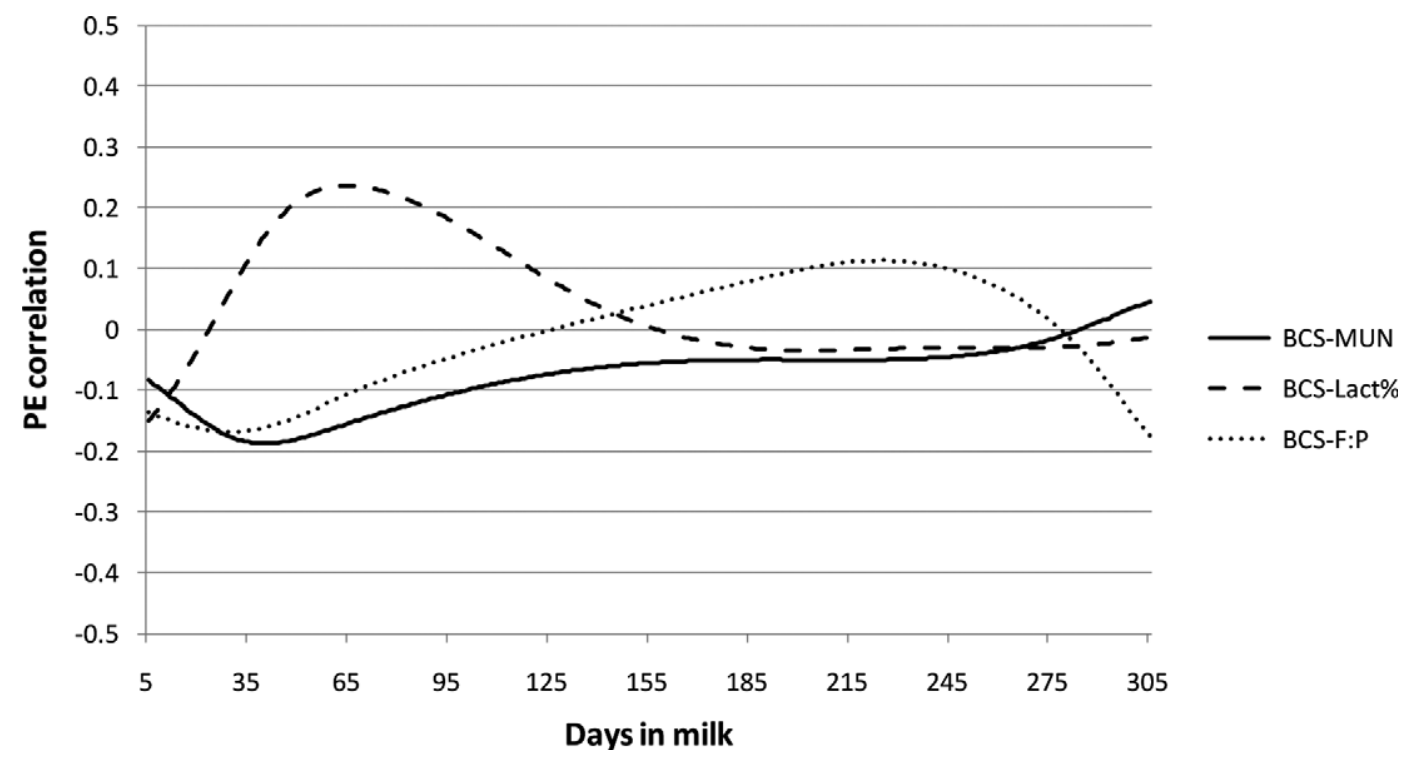

Figure 2. Estimates of permanent environmental (PE) correlations between BCS and MUN, lactose percentage (Lact\%), and fat percentage to protein percentage ratio (F:P) across DIM. 
of 0.23 (0.05), which was different from zero. Perhaps if a negative genetic correlation existed between BCS and protein yield that was weaker than the genetic correlation between BCS and milk yield, this would have a positive influence on Prot\%. The genetic correlation between BCS and SCS was -0.17 (0.06), different from zero), indicating that animals that were genetically inclined to have a higher BCS also had a lower SCS. Berry et al. (2007) did not find that BCS was significantly associated with clinical mastitis. Alternatively, Lassen et al. (2003) found that BCS was genetically negatively correlated with mastitis $(-0.16)$. Using BCS provided by Valacta, Neuenschwander (2010) found a positive additive genetic correlation between BCS and resistance for mastitis.

Daily genetic correlations between BCS and other traits from analyses 1 and 2 are shown in Figures 3 and 4 , respectively. Genes associated with increased BCS in mid to late lactation were associated with reduced milk yield. Genetic correlations were negative and different from zero from 65 DIM onward, excluding 305 DIM. The genetic correlation of zero between BCS and milk yield in early lactation could be because higher milk production and the associated increase in tissue mobilization resulting in a lower BCS would not occur simultaneously, although they would be connected in time. Hence, a delay could occur between cause and effect for changes in BCS and milk production traits. However, a delay of 65 DIM is difficult to explain.

The negative correlation between BCS and milk yield from 65 DIM onward could be an indication of the genes controlling recovery of lost body condition as cows progress through pregnancy, in preparation for the next calving. Body condition score was still moderately heritable at the beginning of lactation (results not shown, but see Loker et al., 2011), when the genetic correlation with milk yield was zero, and the favorable genetic correlations with Prot\% and SCS were strongest. Specifically, Bayesian confidence intervals indicated that the genetic correlations between BCS and milk yield at 5 and 35 DIM were not different from zero. Genetic correlations between BCS and Fat\% were positive and different from zero at 95 and 125 DIM. Genetic correlations between BCS and Prot\% were positive and different from zero up to and including 215 DIM. Genetic correlations between BCS and SCS were negative and different from zero from 35 DIM onward, excluding 305 DIM.

König et al. (2008) calculated a genetic correlation between milk yield and MUN of 0.44 and suggested that the energy deficiency in early lactation was accompanied by an increase in MUN. Those authors found negative genetic correlations of -0.19 and -0.23 between MUN and 56-d and 90-d nonreturn rate, respectively. In addition, Wattiaux and Karg (2004) found a positive correlation between MUN and production efficiency (ratio of 3.5\% FCM to DMI) in early lactation, and therefore suggested that body protein mobilization might affect MUN in early lactation. Given these findings, a negative genetic correlation between BCS and MUN was expected in the current study. Despite the negative PE correlation in early lactation between BCS and MUN, the average daily genetic correlation in the current study was $-0.03(0.07)$ (Table 5$)$, which was

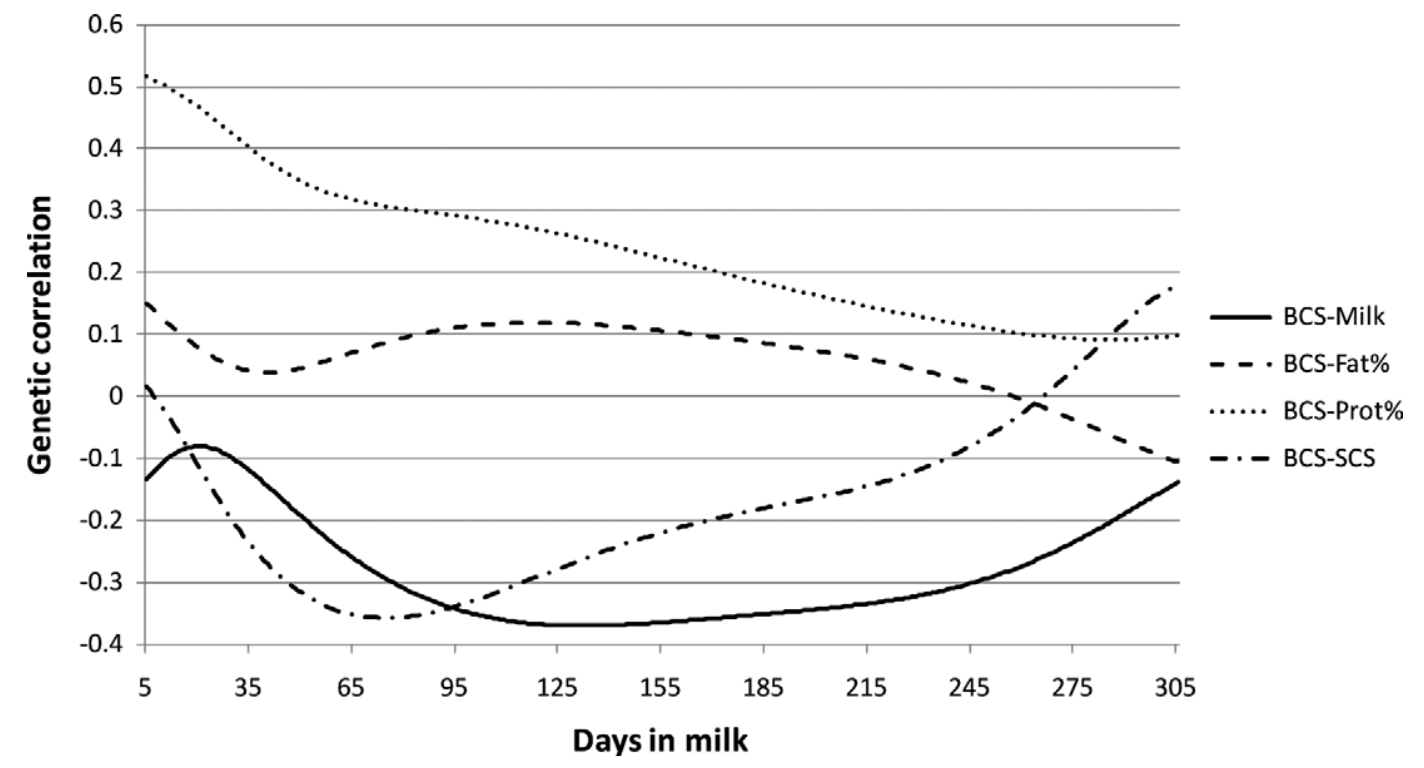
DIM.

Figure 3. Estimates of genetic correlations between BCS and milk yield, fat percentage (Fat\%), protein percentage (Prot\%), and SCS across 
Table 6. Estimates of genetic correlations between BCS and milk production traits for different combinations of DIM

\begin{tabular}{|c|c|c|c|c|c|c|c|c|c|c|c|c|c|c|c|c|}
\hline \multirow[b]{2}{*}{ DIM } & \multicolumn{4}{|c|}{ Milk yield } & \multicolumn{4}{|c|}{ Fat $\%^{1}$} & \multicolumn{4}{|c|}{ Prot $\%^{1}$} & \multicolumn{4}{|c|}{ SCS } \\
\hline & 5 & 50 & 150 & 250 & 5 & 50 & 150 & 250 & 5 & 50 & 150 & 250 & 5 & 50 & 150 & 250 \\
\hline 5 & -0.13 & 0.10 & 0.13 & 0.15 & 0.15 & 0.08 & -0.07 & -0.11 & $0.51^{*}$ & $0.20^{*}$ & -0.03 & -0.10 & 0.01 & -0.14 & -0.07 & -0.05 \\
\hline 50 & -0.06 & $-0.19^{*}$ & $-0.16^{*}$ & -0.09 & -0.08 & 0.04 & 0.04 & 0.02 & $0.40^{*}$ & $0.35^{*}$ & $0.12^{*}$ & 0.02 & -0.03 & $-0.32^{*}$ & $-0.20^{*}$ & $-0.19 *$ \\
\hline 150 & 0.03 & $-0.37^{*}$ & $-0.37^{*}$ & $-0.30^{*}$ & $-0.26^{*}$ & -0.03 & $0.11^{*}$ & 0.10 & $0.24^{*}$ & $0.40^{*}$ & $0.23^{*}$ & $0.12^{*}$ & -0.08 & $-0.38^{*}$ & $0.23^{*}$ & $-0.22^{*}$ \\
\hline 250 & 0.05 & $-0.25^{*}$ & $-0.33^{*}$ & $-0.29^{*}$ & $-0.23^{*}$ & $-0.12^{*}$ & 0.02 & 0.01 & $0.31^{*}$ & $0.35^{*}$ & $0.20^{*}$ & 0.11 & -0.15 & $-0.27^{*}$ & -0.10 & -0.07 \\
\hline
\end{tabular}

${ }^{1}$ Fat $\%=$ fat percentage, Prot $\%=$ protein percentage.

*Different from zero using Bayesian confidence interval.

not different from zero. The genetic correlation between BCS and MUN was not different from zero at any point in the lactation.

Buckley et al. (2003) associated higher Lact\% with increased pregnancy rate, and Reksen et al. (2002) found that higher Lact\% in early lactation was related to early luteal response. Given these findings, in conjunction with studies that associated higher BCS with better fertility (Harrison et al., 1990; de Vries et al., 1999; Dechow et al., 2001; Bastin et al., 2010), a positive genetic correlation between BCS and Lact\% was expected. The average daily genetic correlation between BCS and Lact\% in the current study was 0.11 (0.06) (Table 5), which was not different from zero. However, the positive genetic correlation between BCS and Lact\% was considered different from zero in early lactation at 5 and 35 DIM (Figure 4).

The negative genetic correlation between BCS and $\mathrm{F}: \mathrm{P}$ was different from zero on an average daily basis and in early lactation at 35, 65, and 95 DIM (Figure 4). Grieve et al. (1986) found a negative phenotypic correlation between energy balance and F:P. Likewise, Buttchereit et al. (2010) concluded that F:P is a good indicator of energy balance status. Just before lactation, the typical cow is well conditioned and therefore will mobilize mostly fat reserves in early lactation, when the cow is in negative energy balance. This explains the higher percentage of fat than protein in the milk found by Grieve et al. (1986) in early lactation. Evolutionarily, early lactation is when the calf depends mainly on energy provided by the mother's milk (Friggens, 2003). Therefore, it is logical that the negative genetic correlation between BCS and F:P was strongest in early lactation. A very weak, positive genetic correlation was found between BCS and Fat\% in early lactation, but the strength of the positive genetic correlation between BCS and Prot\% was greater, which could have to do with the negative genetic correlation between BCS and F:P. We could not determine an explanation for this.

Early lactation BCS had the most favorable genetic correlations with milk production traits. Genetic correlations between BCS and milk production traits at dif-

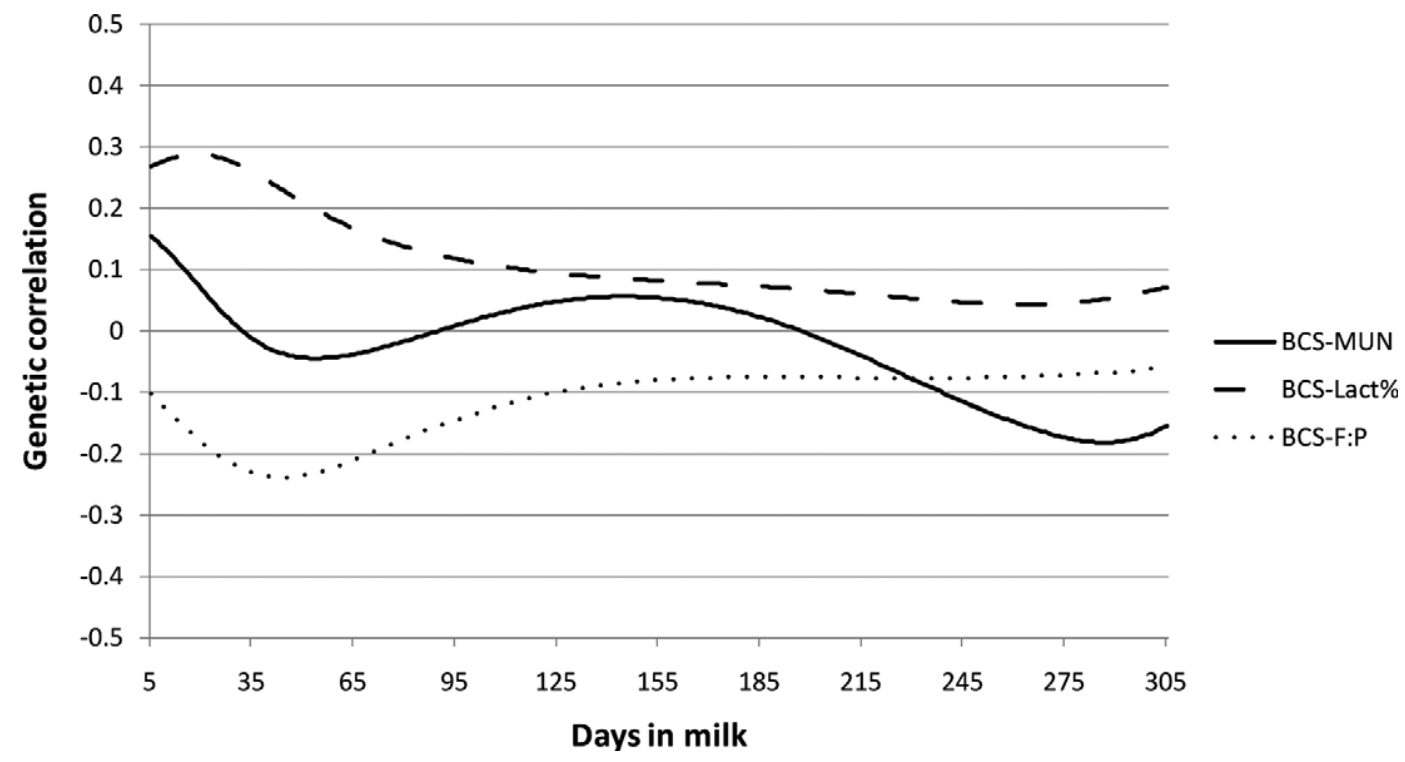

Figure 4. Estimates of genetic correlations between BCS and MUN, lactose percentage (Lact\%), and fat percentage to protein percentage ratio (F:P) across DIM. 
Table 7. Estimates of genetic correlations between BCS and milk production traits for different combinations of DIM

\begin{tabular}{|c|c|c|c|c|c|c|c|c|c|c|c|c|}
\hline \multirow[b]{2}{*}{ DIM } & \multicolumn{4}{|c|}{ MUN } & \multicolumn{4}{|c|}{ Lact $\%^{1}$} & \multicolumn{4}{|c|}{$\mathrm{F}: \mathrm{P}^{1}$} \\
\hline & 5 & 50 & 150 & 250 & 5 & 50 & 150 & 250 & 5 & 50 & 150 & 250 \\
\hline 5 & 0.15 & -0.13 & -0.04 & $-0.19^{*}$ & $0.27^{*}$ & 0.22 & $0.27^{*}$ & 0.16 & -0.10 & -0.06 & -0.01 & -0.005 \\
\hline 50 & 0.17 & -0.04 & 0.02 & $-0.14^{*}$ & $0.31 *$ & $0.21^{*}$ & $0.20 *$ & 0.13 & $-0.31^{*}$ & $-0.24^{*}$ & -0.04 & -0.02 \\
\hline 150 & 0.15 & 0.03 & 0.06 & -0.08 & $0.25^{*}$ & 0.13 & 0.08 & 0.06 & $-0.42^{*}$ & $-0.36^{*}$ & -0.08 & -0.04 \\
\hline 250 & 0.13 & -0.02 & -0.01 & -0.13 & 0.16 & 0.08 & 0.06 & 0.05 & $-0.35^{*}$ & $-0.36^{*}$ & $-0.13^{*}$ & -0.08 \\
\hline
\end{tabular}

${ }^{1}$ Lact $\%=$ lactose percentage, $\mathrm{F}: \mathrm{P}=$ fat percentage to protein percentage ratio.

*Different from zero using Bayesian confidence interval.

ferent combinations of DIM are shown in Tables 6 and 7 (for traits in analyses 1 and 2, respectively). Generally, $\mathrm{BCS}$ at 5 and 50 DIM had the most favorable genetic correlations with milk production traits at 5, 50, 150, and 250 DIM. Body condition score during that early lactation period (compared with BCS at later stages) had the weakest negative genetic correlation with milk yield at different stages of lactation, and was favorably genetically correlated with SCS and Lact\% at different lactation stages. These results indicate that it may be possible to select for increased BCS without a large negative effect on milk production, and that early lactation BCS EBV shows potential for selection.

\section{CONCLUSIONS}

This study is preliminary research progressing toward a genetic evaluation of BCS in Canada using a random regression animal model. This study sought to determine how associations between BCS and milk production traits change over the lactation. Compared with mid- to late-lactation BCS, early-lactation BCS had the most favorable genetic correlations with milk production traits. The level of association that BCS had with milk production traits was not constant over the lactation. Simultaneous selection for both BCS and milk production traits should be considered, mainly due to the unfavorable genetic correlation between BCS with milk yield.

\section{ACKNOWLEDGMENTS}

The authors acknowledge the DairyGen Council of Canadian Dairy Network (Guelph, ON, Canada), and NSERC of Canada (Ottawa, ON, Canada) for funding this project. Authors thank two anonymous reviewers for their helpful suggestions and comments.

\section{REFERENCES}

Bastin, C., S. Loker, N. Gengler, A. Sewalem, and F. Miglior. 2010. Genetic relationships between body condition score and reproduction traits for Canadian Holstein and Ayrshire first-parity cows. J. Dairy Sci. 93:2215-2228.
Bauman, D. E., and W. B. Currie. 1980. Partitioning of nutrients during pregnancy and lactation: A review of mechanisms involving homeostasis and homeorhesis. J. Dairy Sci. 63:1514-1529.

Belyea, R. L., G. R. Frost, F. A. Martz, J. L. Clark, and L. G. Forkner. 1978. Body composition of dairy cattle by potassium-40 liquid scintillation detection. J. Dairy Sci. 61:206-211.

Berry, D. P., F. Buckley, P. Dillon, R. D. Evans, M. Rath, and R. F. Veerkamp. 2003a. Genetic relationships among body condition score, body weight, milk yield, and fertility in dairy cows. J. Dairy Sci. 86:2193-2204.

Berry, D. P., F. Buckley, P. Dillon, R. D. Evans, M. Rath, and R. F. Veerkamp. 2003b. Genetic parameters for body condition score, body weight, milk yield, and fertility estimated using random regression models. J. Dairy Sci. 86:3704-3717.

Berry, D. P., J. M. Lee, K. A. Macdonald, K. Stafford, L. Matthews, and J. R. Roche. 2007. Associations among body condition score, body weight, somatic cell count, and clinical mastitis in seasonally calving dairy cattle. J. Dairy Sci. 90:637-648.

Bewley, J. M., and M. M. Schutz. 2008. Review: An interdisciplinary review of body condition scoring for dairy cattle. Prof. Anim. Sci. 24:507-529.

Buckley, F., K. O'Sullivan, J. F. Mee, R. D. Evans, and P. Dillon. 2003. Relationships among milk yield, body condition, cow weight, and reproduction in spring-calved Holstein-Friesians. J. Dairy Sci. $86: 2308-2319$.

Butler, W. R., and R. D. Smith. 1989. Interrelationships between energy balance and postpartum reproductive function in dairy cattle. J. Dairy Sci. 72:767-783.

Buttchereit, N., E. Stamer, W. Junge, and G. Thaller. 2010. Evaluation of five lactation curve models fitted for fat:protein ratio of milk and daily energy balance. J. Dairy Sci. 93:1702-1712.

de Vries, M. J., S. Van Der Beek, L. M. T. E. Kaal-Lansbergen, W. Ouweltjes, and J. B. M. Wilmink. 1999. Modeling of energy balance in early lactation and the effect of energy deficits in early lactation on first detected estrus postpartum in dairy cows. J. Dairy Sci. 82:1927-1934.

Dechow, C. D., G. W. Rogers, and J. S. Clay. 2001. Heritabilities and correlations among body condition scores, production traits, and reproductive performance. J. Dairy Sci. 84:266-275.

Dechow, C. D., G. W. Rogers, and J. S. Clay. 2002. Heritability and correlations among body condition score loss, body condition score, production and reproductive performance. J. Dairy Sci. 85:3062-3070.

Dechow, C. D., G. W. Rogers, L. Klei, T. J. Lawlor, and P. M. VanRaden. 2004. Body condition scores and dairy form evaluations as indicators of days open in US Holsteins. J. Dairy Sci. 87:35343541.

Friggens, N. C. 2003. Body lipid reserves and the reproductive cycle: Towards a better understanding. Livest. Prod. Sci. 83:219-236.

Grieve, D. G., S. Korver, Y. S. Rijpkema, and G. Hof. 1986. Relationship between milk composition and some nutritional parameters in early lactation. Livest. Prod. Sci. 14:239-254.

Harrison, R. O., S. P. Ford, J. W. Young, A. J. Conley, and A. E. Freeman. 1990. Increased milk production versus reproductive and energy status of high producing dairy cows. J. Dairy Sci. $73: 2749-2758$. 
Heringstad, B., Y. M. Chang, D. Gianola, and G. Klemetsdal. 2003. Genetic analysis of longitudinal trajectory of clinical mastitis in first-lactation Norwegian Cattle. J. Dairy Sci. 86:2676-2683.

Hooven, N. W., Jr., R. H. Miller, and J. W. Smith. 1972. Relationships among whole- and part-lactation gross feed efficiency, feed consumption, and milk yield. J. Dairy Sci. 55:1113-1122.

Jones, H. E., I. M. S. White, and S. Brotherstone. 1999. Genetic evaluation of Holstein Friesian sires for daughter condition-score changes using a random regression model. Anim. Sci. 68:467-475.

Koenen, E. P. C., R. F. Veerkamp, P. Dobbelaar, and G. De Jong. 2001. Genetic analysis of body condition score of lactating Dutch Holstein and Red-and-White heifers. J. Dairy Sci. 84:1265-1270.

König, S., Y. M. Chang, U. U. v. Borstel, D. Gianola, and H. Simianer. 2008. Genetic and phenotypic relationships among milk urea nitrogen, fertility, and milk yield in Holstein cows. J. Dairy Sci. 91:4372-4382.

Lassen, J., M. Hansen, M. K. Sørensen, G. P. Aamand, L. G. Christensen, and P. Madsen. 2003. Genetic relationship between body condition score, dairy character, mastitis, and diseases other than mastitis in first-parity Danish Holstein cows. J. Dairy Sci. 86:3730-3735.

Loker, S., C. Bastin, F. Miglior, A. Sewalem, L. R. Schaeffer, J. Jamrozik, and V. Osborne. 2011. Short communication: Estimates of genetic parameters of body condition score in the first 3 lactations using a random regression animal model. J. Dairy Sci. 94:36933699 .

Madsen, P., and J. Jensen. 2008. DMU: A user's guide. A package for analysing multivariate mixed models. Version 6 , release 4.7. DJF, Foulum, Denmark. http://www.dmu.agrsci.dk/.

Miglior, F., B. L. Muir, and B. J. Van Doormaal. 2005. Selection indices in Holstein cattle of various countries. J. Dairy Sci. 88:12551263.

Miglior, F., A. Sewalem, J. Jamrozik, J. Bohmanova, D. M. Lefebvre, and R. K. Moore. 2007. Genetic analysis of milk urea nitrogen and lactose and their relationships with other production traits in Canadian Holstein cattle. J. Dairy Sci. 90:2468-2479.
Neuenschwander, T. 2010. Studies on disease resistance based on producer-recorded data in Canadian Holsteins. PhD Thesis. University of Guelph, Guelph, ON, Canada.

Reksen, O., Ø. Havrevoll, Y. T. Gröhn, and T. Bolstad. 2002. Relationships among body condition score, milk constituents, and postpartum luteal function in Norwegian dairy cows. J. Dairy Sci. 85:1406-1415.

Schaeffer, L. R., J. Jamrozik, G. J. Kistemaker, and B. J. Van Doormaal. 2000. Experience with a test-day model. J. Dairy Sci. $83: 1135-1144$

Schröder, U. J., and R. Staufenbiel. 2006. Invited review: Methods to determine body fat reserves in the dairy cow with special regard to ultrasonographic measurement of backfat thickness. J. Dairy Sci. 89:1-14.

Searle, S. R. 1982. Matrix Algebra Useful for Statistics. John Wiley \& Sons Inc., New York, NY.

van Arendonk, J. A. M., G. J. Nieuwhof, H. Vos, and S. Korver. 1991. Genetic aspects of feed intake and efficiency in lactating dairy heifers. Livest. Prod. Sci. 29:263-275.

Veerkamp, R. F., and S. Brotherstone. 1997. Genetic correlations between linear type traits, food intake, live weight and condition score in Holstein Friesian dairy cattle. Anim. Sci. 64:385-392.

Veerkamp, R. F., and G. C. Emmans. 1995. Sources of genetic variation in energetic efficiency of dairy cows. Livest. Prod. Sci. 44:87-97.

Veerkamp, R. F., E. P. C. Koenen, and G. de Jong. 2001. Genetic correlations among body condition score, yield, and fertility in first-parity cows estimated by random regression models. J. Dairy Sci. 84:2327-2335.

Veerkamp, R. F., G. Simm, and J. D. Oldham. 1995.Genotype by environment interaction-Experience from Langhill. Pages 59-66 in Breeding and Feeding the High Genetic Merit Dairy Cow. Occas. Publ. 19. T. L. J. Lawrence, F. J. Gordon, and A. Carson, ed. Br. Soc. Anim. Sci., Edinburgh, UK.

Wattiaux, M. A., and K. L. Karg. 2004. Protein level for alfalfa and corn silage-based diets: I. Lactational response and milk urea nitrogen. J. Dairy Sci. 87:3480-3491. 